\title{
Sugar chromatography of urine and faeces in acute gastroenteritis
}

\author{
J. G. MCCORMACK* \\ M.B., D.C.H., M.R.C.P.I.
}

Department of Infectious Diseases and Department of Pathology, Seacroft Hospital, Leeds LS14 6UH, Westiv Yorkshire

\begin{abstract}
Summary
Sugar chromatography was performed on urine and faecal specimens obtained at admission from $\mathbf{4 8 2}$ children under the age of five years admitted to hospital because of acute gastroenteritis. The sensitivity of the chromatography was such that $2 \mu \mathrm{g}$ of the various sugars could be detected, which is equivalent to $5 \mathrm{mg}$ per $\mathrm{g}$ of stool, and this level was considered a positive result. Fifty-nine $(12 \cdot 2 \%)$ children without any clinically apparent milk intolerance had sugar chromatographic abnormalities, in 32 of whom a disaccharide was found in the urine and/or faeces. Twenty-one children, all under the age of nine months, developed a relapse of their diarrhoea when full strength milk was reintroduced. In only one of these cases, a two-month-old boy with sucrose in his urine, was a disaccharide found on chromatography.

It is concluded that testing for disaccharides in urine or faeces by chromatography in children with acute gastroenteritis is of no value in predicting who is likely to suffer from clinical relapse when milk feeding is subsequently recommenced.
\end{abstract}

\section{Introduction}

Relapse of diarrhoea following the reintroduction of milk feeding in infants recovering from acute gastroenteritis is a frequently encountered problem in clinical practice. Suggested explanations for this include: disaccharide (especially lactose) intolerance, cow's milk protein hypersensitivity, local intestinal IgA deficiency and the presence of lactulose in some proprietary milk preparations (Burke, Kerry and Anderson, 1965; Eastham and Walker, 1979; Harrison et al., 1979; Hendricks, Wooldridge and Russell, 1977).

There is no way of predicting which children with acute gastroenteritis are subsequently likely to suffer a relapse of their bowel symptoms when milk feeds

* Present Address: Tawam Hospital, P.O. Box 15258, Al Ain, Abu Dhabi, United Arab Emirates. are reintroduced. Identification of such children in advance by easy, reliable tests could permit preven- $\infty$ tion of such a relapse by omission of responsible $\infty$ agents from the feeds. It has been postulated that the or commonest pathogenetic factor in such relapses is $\stackrel{+}{\infty}$ disaccharide intolerance (Eastham and Walker, 은 1979). It was speculated that since this intolerance develops as a result of infection by the original agent $\omega$ responsible for the gastroenteritis, one would expect $\mathbb{D}$ to find evidence of undigested disaccharides in the faeces or urine at the onset of the illness. It was hoped 0 that identification of these compounds might predieg which children would subsequently suffer a relapse $\overrightarrow{0}$ due to disaccharide intolerance and that sucti children would benefit from disaccharide-free mill: feeding during the early convalescent period.

\section{Methods}

A stool and urine specimen were collected as soon as possible from children under the age of five years referred to a regional infectious diseases unit because of acute gastroenteritis between May 1978 and April 1979 inclusive. All of these patients were considered sufficiently ill to require admission to hospital from their homes. Although it was not possible to estimate the disaccharide load to which the children had been exposed before admission, no correlation was noted between a particular form of feeding and subsequent sugar chromatography results. If not tested immediately, specimens were stored at $4^{\circ} \mathrm{C}$.

The specimens were analysed for sugars by one dimensional thin layer chromatography on cellulose. Ethyl acetate-pyridine-water $(66: 26: 8)$ was used for development (Kudla and McVean, 1968), and the aniline-diphenylamine reagent was used for detection (Smith, 1960). Two $\mu$ l of urine or of a 1:5 faecal emulsion was applied to the chromatogram. Two $\mu \mathrm{g}$ of lactose, sucrose, glucose, galactose or fructose could be detected on the chromatogram, which was found to be equivalent to $5 \mathrm{mg}$ of sugar per $\mathrm{g}$ of faeces. The presence of glucose was confirmed by 
TABLE 1. Sugar chromatography of urine and faeces of children with clinical milk intolerance

\begin{tabular}{|c|c|c|c|c|}
\hline \multirow{2}{*}{$\begin{array}{l}\text { Case(s) } \\
\text { No. }\end{array}$} & \multicolumn{2}{|c|}{ Sugar chromatography } & \multirow{2}{*}{$\begin{array}{l}\text { Organisms } \\
\text { found }\end{array}$} & \multirow[b]{2}{*}{ Treatment } \\
\hline & Urine & Faeces & & \\
\hline 1 & Sucrose & Neg. & None & $\begin{array}{l}\text { i.v. fluids used } \\
\text { Settled on Prosobee }\end{array}$ \\
\hline 2 & $\begin{array}{l}\text { Glucose \& } \\
\text { galactose }\end{array}$ & Neg. & None & $\begin{array}{l}\text { i.v. fluids used } \\
\text { Settled on Nutramigen }\end{array}$ \\
\hline 3 & Neg. & Glucose & None & $\begin{array}{l}\text { i.v. fluids used } \\
\text { Settled on original milk }\end{array}$ \\
\hline 4 & Neg. & Glucose & Adenovirus & $\begin{array}{l}\text { i.v. fluids used } \\
\text { Settled on Nutramigen }\end{array}$ \\
\hline $5-21$ & Neg. & Neg. & $\begin{array}{l}\text { None (9) } \\
\text { Rotavirus (5) } \\
E . \text { coli (4) } \\
\text { Adenovirus (3) } \\
\text { Shigella (1) }\end{array}$ & $\begin{array}{l}\text { i.v. fluids used in } 5 \text { cases } \\
9 \text { settled on Prosobee } \\
2 \text { settled on Nutramigen } \\
6 \text { settled on original milk }\end{array}$ \\
\hline
\end{tabular}

an oxidase-perodixase method (Ames, Clinistix*). Sucrose and lactose were further characterized by enzymic or acid hydrolysis, the monosaccharides produced being identified by chromatography.

The initial management of these children consisted of either intravenous or oral glucose and saline. No antibiotics were used. When the frequency and severity of the diarrhoea and vomiting were improving, usually within one to three days, the same type of milk as the child had been using previously was reintroduced, starting with half strength milk with water, progressing to three quarters and full strength milk on successive days. A child was defined as having clinical milk intolerance if, before full strength milk could be established, he had a relapse of his diarrhoea which did not resolve within 24 hours. Such patients were recommenced on oral glucose and saline for $\mathbf{2 4}$ hours and the same milk reintroduced in a similar pattern to that described above. If another relapse occurred which did not resolve within 24 hours, feeding with either Nutramigen $\dagger$ or Prosobee $\ddagger$ was commenced.

\section{Results}

Four hundred and eighty-two children were studied, of whom 280 were male and 202 were female. The mean age was 11.6 months. Electron microscopy (EM) and virological and bacteriological cultures of faeces failed to reveal a potentially pathogenic organism in $222(46 \%)$ of the patients. Rotaviruses were detected by faecal EM in 120 cases (25\%), adenoviruses were found in 62 cases, enterotoxigenic $E$. coli in 31 , and smaller numbers of other pathogens, e.g. salmonellae, shigellae, ECHO viruses, campylobacter and Giardia lamblia were noted. Approximately one patient in five required intravenous fluid therapy and the mean duration of the diarrhoea was 4.7 days. Further details of the clinical and aetiological features of the study are presented elsewhere (McCormack, 1982).

Twenty-one children ( $4.4 \%)$ were defined by the above criteria as having clinical milk intolerance. Of these, 17 had no sugar detected in urine or faeces and in only one instance was a disaccharide found (Table 1). All patients in this group were under the age of nine months and none were being breast fed before the onset of the illness.

Fifty-nine children, without clinical milk intolerance, displayed an abnormality in their stool or urine chromatograms (Table 2). Disaccharides were found in 32 cases and were more often found in urine than faeces. A disproportionate number of the patients with disaccharides in urine or faeces $(47 \%)$ had rotavirus gastroenteritis, otherwise there was no significant assosiation between any particular aetiological agent and either clinical milk intolerance or positive stool sugar chromatography.

TABLE 2. Numbers of patients without clinical milk intolerance with abnormal urine or faecal sugar chromatograms

\begin{tabular}{lcc}
\hline & $\begin{array}{c}\text { Disaccharide } \\
\text { abnormalities }\end{array}$ & $\begin{array}{c}\text { Monosaccharide } \\
\text { abnormalities }\end{array}$ \\
\hline Faeces only & 13 & 24 \\
Faeces \& urine & 2 & 2 \\
Urine only & 17 & 1 \\
Total & 32 & 27 \\
\hline
\end{tabular}

* Ames Company, Stoke Poges, Slough, England.

† Hydrolysed protein lactose-free product, Mead Johnson Division, Bristol Laboratories, Langley, Slough, England.

$\ddagger$ Lactose and cow's milk protein-free soyabean product, Mead Johnson Division, Bristol Laboratories, Langley, Slough, England. 


\section{Discussion}

The original hope, of establishing early faecal or urine chromatographic detection of disaccharides as a predictor of subsequent clinical milk intolerance in a significant number of children with acute gastroenteritis, was not realized. Some of the cases of clinical milk intolerance in the study may have been caused by other factors as described above, but lactose intolerance is considered to be the most common pathogenic factor in this condition (Eastham and Walker, 1979). Perhaps disaccharides would have appeared in faeces or urine when the milk feeds were reintroduced, but at that stage such detection may be too late to influence subsequent management.

The significance of the positive sugar chromatograms, especially those positive for disaccharides, in children without clinical milk intolerance, is not clear. Possibly these patients suffered from a subclinical form of disaccharide intolerance, but this idea is speculative. The high incidence of disaccharide-positive faecal and urine specimens in the rotavirus gastroenteritis patients may correlate with the low disaccharidase activity reported in intestinal samples of such patients (Trier, Schreiber and Blacklow, 1977), and may provide a further clue to the pathogenic mechanism of the diarrhoea in this illness.

\section{Acknowledgments}

We wish to thank Dr J. Stevenson and Dr H. Pullen for allowing $C$ us to study patients under their care and Dr J. Littlewood for his very helpful advice.

\section{References}

BURKE, V., KERRY, K.R. \& ANDERSON, C.M. (1965) The relation- $\frac{\bar{T}}{\bar{D}}$ ship of dietary lactose to refractory diarrhoea in infancy. $\triangle$ Australian Paediatric Journal, 1, 147.

EASTHAM, E.J. \& WALKER, W.A. (1979) Adverse effects of milk (S formula ingestion on the G.I.T. Gastroenterology, 76, 365.

HARRISON, M., KILbY, A., WALKER-Smith, J.A., FrANCE, N.E. \& Wood, C.B.S. (1979) Cow's milk protein intolerance: a possible $\vec{\omega}$ association with gastroenteritis, lactose intolerance and $\operatorname{IgA} \sigma$ deficiency. British Medical Journal, 1, 1501.

HENDRICKS, R.G., WOOLDRIDGE, M.A.W. \& RuSSELl, A. (1977) Lactulose in baby milks causing diarrhoea simulating lactose intolerance. British Medical Journal, i, 1184.

KUDLA, R.M. \& MCVEAN, D.E. (1968) Semiquantitative separation of carbohydrates in urine by thin-layer chromatography. American Journal of Clinical Pathology, 49, 279.

MCCORMACK, J.G. (1982) Clinical features of rotavirus gastroenteritis. Journal of Infection, 4, 167.

SMITH, I. (1960) Chromatographic and Electrophoretic Techniques, 1st 윽 edn, William Heinemann, London.

Trier, J.S., SChreiber, D.S. \& BlaCKLOW, N.R. (1977) The $\vec{c}$ pathology of acute non-bacterial gastroenteritis. In: The Gastro. $\mathbb{D}$ intestinal Tract (ed. by Yardley, J.H., Morson, B.C. and Abell, M.R.), lst edn, p. 36. Williams \& Wilkins, Baltimore. 